\title{
Una interjección de Sucre ${ }^{1}$
}

\author{
José Luis Ayala \\ Universidad Ricardo Palma \\ munasnawa@yahoo.com
}

\section{Resumen}

Ricardo Palma asevera que el general José Antonio de Sucre era un militar culto, quien casi nunca se expresaba con palabras cargadas de doble significado o de connotación grosera. Al contrario, gozaba de un evidente prestigio moral y ético, no solo ante el propio general Simón Bolívar sino también entre los oficiales que lo conocían. Sucre era además de buen amigo, una persona leal de quien Bolívar pensaba que algún día le sucedería en el mando y construcción de la nuevas Repúblicas. Es por esa razón que Ricardo Palma, nombra una palabra expresada por Sucre, como una evidente rareza en el lenguaje del héroe asesinado en Berruecos.

Palabras Clave: cartas, interjección, lenguaje culto, Sucre, Bolivar, Palma

\section{Abstract}

Ricardo Palma asserts that General José Antonio de Sucre was a cultured military man, who almost never expressed himself with words loaded with double meanings or coarse connotations. Quite the opposite, he enjoyed an evident moral and ethical prestige, not only from the standpoint of his own General Simon Bolivar, but among the officers who knew him. Sucre was also a good friend, a loyal person whom Bolivar thought would succeed him some day in the command and the building of the new Republics. It is for that reason that Ricardo Palma names a word expressed by Sucre, as an evident rarity in the language of the murdered hero in Berruecos.

Keywords: letters, interjection, cultured language, Sucre, Bolivar, Palma

1 Palma Ricardo (1995) La pinga de Bolívar y otras tradiciones. En: Tradiciones en salsa verde. Págs. 45-47. Lima: Ediciones La Frontera. 
José Luis Ayala Olazával, escritor, poeta, ensayista, narrador y periodista. Ha publicado más de sesenta libros, entre los cuales se pueden mencionar: Celebración del universo, Carlos Oquendo de Amat, Literatura y cultura aymara, Morir en Ilave, Juan Basilio Catacora Heredia, Esta agonía sin fin: Fernando Túpac Amaru Bastidas, Mariátegui y la guerra del Chaco, Huancho Lima, José Fermín de Sata y Busy. El pez de oro de Gamaliel Churata (edición crítica), Juan Bautista Túpac Amaru Monxarras, Nación aymara, Carta a los peruanos del siglo XX, Los abismos de Mario Vargas Llosa. 
Simón Bolívar llamó a Antonio José de Sucre, "Abel americano", luego de conocer su increíble asesinato cuando se dirigía a Quito en las montañas de Berruecos, situadas a escasos $70 \mathrm{~km}$ al Norte de Pasto, en Colombia. El Libertador al conocer la noticia dijo: "Como soldado fuiste la victoria, como magistrado la justicia, como vencedor la clemencia y como amigo la lealtad". Expresión de homenaje y reconocimiento a un hombre íntegro que luchó por la Independencia de América del Sur.

Fue el 4 de junio de 1830 cuando se cometió el más vil de los asesinatos políticos. Antonio José Francisco Sucre y Alcalá, nació el 3 de febrero de 1795. Recibió el título de Gran Mariscal de Ayacucho y prócer de la Independencia Americana. Diplomático, estadista, presidente de Bolivia, General en Jefe del Ejército de la Gran Colombia. Participó en las guerras de Independencia Hispanoamericana, siendo la más memorable la Batalla de Ayacucho. Sin embargo, no se puede dejar de mencionar la Batalla de Pichincha, ocurrida el 24 de mayo de 1822.

Se ha escrito muchos libros acerca de la biografía y notables hechos históricos de Sucre. Ahora no será necesario hacer una síntesis de cuanto se ha dicho, sino más bien presentar las dos últimas cartas que escribió al Libertador Simón Bolívar, la primera desde Bogotá con fecha de 8 de mayo de 1830 .

Su excelencia: Cuando he ido a casa de Ud. para acompañarlo, ya se había marchado. Acaso es esto un bien, pues me ha evitado el dolor de la más penosa despedida. No son palabras las que pueden fácilmente explicar los sentimientos de mi alma respecto a Ud.; Ud. las conoce, pues me conoce mucho tiempo y sabe que no es su poder, sino su amistad la que me ha inspirado el más tierno afecto a su persona. Lo conservaré, cualquiera que sea la suerte que nos quepa, y me lisonjeo que Ud. me conservará siempre el aprecio que me ha dispensado. Sabré en todas 
circunstancias merecerlo. Adiós, mi general, reciba Ud. por gaje de mi amistad las lágrimas que en este momento me hace verter la ausencia de Ud. Sea Ud. feliz en todas partes y en todas partes cuente con los servicios y con la gratitud de su más fiel y apasionado amigo.

A.J. de Sucre².

La última carta de Sucre es un extraño manuscrito escrito desde Bogotá en el mes de mayo de 1830; se trata de un texto breve a modo de despedida. A pesar de faltarle algunas palabras por haber sido maltratado el papel por razones que se desconocen, el contenido sin embargo es sorprendente.

Bogotá, mayo 25 de 1830

Mi querido Bolívar:

De pronto debo partir para Quito donde está el reposo tan deseado y al alejarme de todas las luchas políticas, quiero antes avisarle mi adiós y mi eterno cariño. Dios bien sabe cuánto hemos luchado por la libertad de todas estas tierras y cuán mal nos han pagado. Sé que al alejarme no me guía ningún síntoma de cobardía y de traición, sólo el gran amor y cariño a mi esposa e hija, las cuales hace mucho tiempo que no abrazo, me obligan a ello y también para dejar el puesto a todos nuestros enemigos, que con sus apetitos y sus falacias llevan la República al caos y a la ruina.

Allá, en el remanso de [palabra rota] da pu [palabra rota] la, en la belleza de mi [ilegible]. Sie[mpre roto] [ten]drá usted, noble y viejo amigo un puesto de honor, y [palabra rota] no de quien lo quiere de veras.

A.J. de Sucre $^{3}$

2 Cartas encontradas en: https://www.aporrea.org/actualidad/a241090.html

3 Ibíd. 
Aunque, como señala el historiador Tomás Straka, la carta tiene serías incongruencias, debido a que Sucre llamó siempre al Libertador "Su excelencia", se trata de una acción inusual y un abuso de confianza. Pero además, se supone que esta misiva no pudo haber llegado tan pronto a Bolívar debido a que en ese tiempo se usaban caballos y mulas para trasladar la correspondencia del correo.

De todos modos, el asesinato de Sucre fue uno de los más horrendos sicariatos de la Historia de las guerras por la Independencia Americana. Tres hipótesis se han esgrimido al respecto: El interés de los criollos que no participaron en las guerras, pero que vieron disminuidos el poder político que heredaron. La necesidad de establecer un gobierno colonial sin necesidad de otorgar derechos al pueblo democráticamente organizado. Cortar de raíces las repercusiones posteriores del Congreso de Panamá más conocido como Congreso Anfictiónico de Panamá, convocado por el Libertador Simón Bolívar y realizado en la ciudad de Panamá en 1826.

La idea central de Bolívar era forjar la unión política o una Confederación de los Estados de América, formados en base a los antiguos virreinatos, tal como lo había propuesto antes Francisco de Miranda ${ }^{4}$. El congreso se realizó en el antiguo convento de San Francisco en Panamá. Estuvieron presentes la delegación de México, la Gran Colombia, Perú, República Federal de Centro América. Estados Unidos y Bolivia no llegaron a tiempo. Las Provincias Unidas del Río de La Plata y Chile no tuvieron interés. Paraguay no fue invitado. El Imperio

4 Francisco de Miranda. (Caracas, 28/03/1750-San Fernando, Cádiz, 14/07/1816). Militar, político, diplomático, escritor, humanista e ideólogo, precursor de la Emancipación Americana. Primer venezolano universal y americano más universal. Participó en la Independencia de los Estados Unidos, la Revolución Francesa y de Venezuela. Gobernó la Primera República de Venezuela como Dictador Plenipotenciario y Jefe Supremo de los Estados de Venezuela 
de Brasil mostró un especial desdén. Gran Bretaña acreditó a un observador así como los Países Bajos. Como se sabe, este proyecto fue saboteado y finalmente Bolívar mostró su profunda decepción.

Al conocer el asesinato de Sucre, el Libertador Simón Bolívar en principio quedó anonadado. Luego preguntó varias veces cómo había sucedido el hecho y qué se proponían hacer quienes habían ordenado su muerte. Como por la distancia no era posible saber la verdad, sus enemigos no se atrevieron a reconocer el asesinato y menos lanzado después de un proyecto político. El Libertador entonces dijo: "Lo han matado porque era mi sucesor". El Mariscal de Ayacucho, general don José Antonio de Sucre, tenía entonces 35 años.

Como los enemigos de Simón Bolívar no pudieron consumar la conspiración política para matarlo a él, decidieron cegar la vida de Sucre. El hecho ocurrido en Berruecos fue veinte meses después, o sea la noche del 25 de septiembre de 1828. La consigna que hicieron circular los enemigos de la Independencia Americana, particularmente de Bolívar, fue: "Muerto Sucre, a Bolívar lo matará la tuberculosis en poco tiempo".

Ricardo Palma en referencia al asesinato de Sucre en el libro Tradiciones en salsa verde, empieza narrando:

El mariscal Antonio José de Sucre fue un hombre muy culto y muy decoroso en palabras. Contrastaba en esto con Bolívar. Jamás se oyó de su boca un vocablo obsceno, ni una interjección de cuartel, cosa tan común entre militares. Aun cuando (lo que fue raro en él) se encolerizaba por gravísima causa, limitábase a morderse los labios; puede decirse que tenía lo que llaman la cólera blanca. 
Tal vez fundaba su orgullo en que nadie pudiera decir que lo había visto proferir una palabra soez, pecadillo de que muchos santos, con toda su santidad, no se libraron.

El mismo Santo Domingo cuando, crucifijo en mano, encabezó la matanza de los aborígenes, echaba cada Sacre non de Dieu y a cada rato, que hacía temblar al mundo y sus alrededores. (Palma, 2018: 15)

Los documentos firmados por Sucre denotan el cultivo de un lenguaje depurado. Sus arengas reflejan la lectura de los enciclopedistas, su formación política sin duda tiene como fundamento y proyección el libro El contrato social de Juan Jacobo Rousseau. Es preciso agregar la persistente presencia de una idea central «El hombre nace libre, pero en todos lados está encadenado». También influyeron en su personalidad el libro Emilio o De la educación: "El hombre es bueno por naturaleza".

Ricardo Palma luego escribe con un adecuado lenguaje:

Quizás tienen ustedes noticia del obispo, señor Cuero, arzobispo de Bogotá y que murió en olor de santidad, pues su Ilustrísima, cuando el Evangelio de la misa era muy largo, pasaba por alto algunos versículos, diciendo: Estas son pendejadas del Evangelista y por eso no las leo. (Ibídem)

Luego, se refiere al general William Miller nacido en Inglaterra y muerto en Lima en 1861. Miller ingresó al ejército de su país en 181 l y llegó a Lisboa formando las tropas de la corona británica junto con el ejército portugués y españoles, para luchar contra las tropas invasoras de Napoleón Bonaparte. Estuvo presente en las batallas de Ciudad Rodrigo, San Sebastián y Badajoz, como en la batalla Vitoria, debido al triunfo obtenido y a la derrota de las tropas francesas y luego de expulsarlas de España. Después de la guerra anglo-estadounidense de 1812 viajó a Sevilla y 
Cádiz. Convencido de que su experiencia guerrera serviría en América, se embarcó en Gibraltar con destino a Lima.

En 1817, acompañado por varios de sus compañeros de armas decidió trasladarse a América; primero llegó a Argentina y se presentó para servir en el Ejército Libertador; se le asignó el grado de capitán de artillería y cruzó los Andes. Estuvo presente en la Independencia de Chile. En 1818, con la invasión de reconquista de Mariano Osorio, el Ejército de Chile y el Libertador de los Andes fueron atacados en Cancha Rayada, Miller luchó heroicamente contra el ejército de España invasora. Ese hecho le valió ser amigo por toda la vida del general José de San Martín. Cuando el general argentino se retiró del Perú, Miller pasó a formar el Ejército Unido Libertador.

En 1824, el Libertador Simón Bolívar lo nombró general en jefe de la caballería y con ese grado intervino en las batallas de Junín, Corpahuaico y Ayacucho. Durante la batalla de Ayacucho fue varias veces herido con cortes de sable. Cuando se entrevistó con el Libertador Simón Bolívar, le dijo: "Señor, usted cada vez tiene más cicatrices en el cuerpo". Miller respondió: "Es verdad su excelencia. Así es, lo que sucede es que la muerte no me quiere".

Su conducta, desempeño militar y valentía le valió para ser ascendido al grado de Mariscal del Ejército del Perú. En 1821 intervino en la creación del regimiento de caballería Húsares de Junín. Después de la batalla de Ayacucho, fue nombrado gobernador de la Villa Imperial de Potosí en 1825. En 1828 con el apoyo de su hermano John Miller publicó en Londres: "Memorias del General Miller, al servicio de la República del Perú", texto que tuvo una gran difusión. Vivió sus últimos años en Lima y sintiendo la cercanía de su muerte, fue trasladado a un buque británico en el Callao, donde falleció a los 66 años. 
Ricardo Palma prosigue y dice:

Sólo el mariscal Miller fue, entre los prohombres de la patria vieja, el único que jamás empleó en sus rabietas el cuartelero icarajo!

Él juraba en inglés y por eso un God dam! de Miller (Dios me condene), a nadie impresionaba. Cuentan del bravo británico que, al escapar de Arequipa perseguido por un piquete de caballería española, pasó frente a un balcón en el que estaban tres damas godas de primera agua, las que gritaron al fugitivo:

- iAbur, gringo pícaro!

Miller detuvo al caballo y contestó:

— Lo de gringo es cierto y lo de pícaro no está probado, pero lo que es una verdad más grande que la Biblia es que ustedes son feas, viejas y putas. God dam! (Ibídem)

En cambio, Simón Bolívar no se permitía soltar palabras obscenas ni cuando tenía grandes dolores en la sentadera y las nalgas, por lo que sus soldados no decían por ejemplo el señor general o El Libertador, sino el culo de fierro.

Volviendo a Sucre, - dice Palma - de quien la digresión milleresca nos ha alejado un tantico, hay que traer a cuento el aforismo que dice: "Nadie diga de esta agua no beberé".

El día de la horrenda, de la abominable tragedia de Berruecos, al oírse la detonación del arma de fuego, exclamó Sucre, cayendo del caballo:

— iCarajo!, un balazo...

Y no pronunció más palabra. (Ibíd: 15-16) 
La palabra carajo proviene de la edad media habiendo nacido en las grandes expresiones marinas. Por tanto, tiene una antigüedad y vigencia de más de mil años. En las naves antiguas, en lo alto, había un lugar en que uno de los marinos subía para divisar a gran distancia la llegada a destino de algún barco enemigo u otros obstáculos. Como es ese lugar golpean los húmedos y helados vientos marinos, quienes subían por medio de sogas eran enviados al "carajo".

En holandés a este sitio en el tope del mástil se le llama "nido de grajo" y quienes iban a ese lugar sufrían las inclemencias de los vientos, la expresión traducida al español quedó registrada como: "enviados al carajo". En los romanceros hispánicos en portugués de decía caralho y en catalán carall. Sin embargo, es imposible determinar su etimología porque ninguna propuesta es convincente. En castellano se registró por primera vez en el Cancionero de Baena, hacia 1400. Se trata de un texto lleno de palabras obscenas, así por ejemplo se lee: iVete al carajo! iNo me importa un carajo! iNo vale un carajo!

Carajo, sin embargo, es una palabra vulgar que se refiera al pene, al miembro viril. Es una interjección grave. Una expresión de disgusto, rechazo o desprecio usada para exteriorizar el mal humor, enfado, y para protestar o quejarse. Es también echarse a perder, estropearse. Despedir, rechazar a una persona con malos modales, con desprecio. Persona a la que en una conversación no se quiere mencionar para desvalorizarla. Sirve para expresar sorpresa, contrariedad, un susto una molestia.

Desde entonces, — escribe Ricardo Palma- quedó como refrán el decir a una persona, cuando jura y rejura que en su vida no cometerá tal o cual acción, buena o mala:

- iHombre, quién sabe si no nos saldrá usted un día con el Carajo de Sucre! Berruecos: despoblado en Colombia, 
en donde fue traidoramente asesinado el general Sucre, haciéndose fuego desde unos matorrales ocultos. (Ibíd.:16)

\section{Bibliografía}

Palma, R. (1995) El carajo de Sucre. En: Tradiciones en salsa verde. Págs. 15-16. (O.L): Red Ediciones S.L. Consultado en https://books.google. com.pe/books?id=yDP51Ck77NUC\&pg $=$ PA15\&lpg $=$ PAl $5 \& d q=$

Recibido el 13 de diciembre del 2017 Aprobado el 29 de enero del 2018 